\title{
CONTROL METHODS ANALYSIS OF SWITCHED RELUCTANCE MACHINE
}

\begin{abstract}
The paper presents results of simulation studies of four-phase 8/6 Switched Reluctance Machine working in steady-state. Simulation model of the machine was developed in Matlab/Simulink based on mathematical model. Simulation model was realized based on SimPowerSystems library, which contains for example models of semiconductor elements or power supplies. Controllable current sources and voltage measurement blocks were also used. Mathematical description of the machine is difficult to obtain in nonlinear circuit simulation models. Nonlinear flux characteristics $\psi(\theta, i)$ were obtained by field calculations and then were tabulated and used in circuit model of the machine. Studies were concerned the change of working point influence of motor on basic parameters especially on electromagnetic torque with various basic control methods (current control: soft-chopping and hard-chopping, voltage control: soft and hard, and one-pulse control). In current control was only used hysteresis regulator which held phase current at a certain level. Current control is possible to base speed, voltage control with its particular case called single-pulse control has wider use because it can be used above base speed, but for high-speed operation single-pulse control is used.
\end{abstract}

Keywords: simulation model, current control, voltage control, single-pulse control

\section{Introduction}

Switched Reluctance Machines [1,2] belong to the group of machines with electronic commutation. Due to simple construction, possibility of work in wide speed range they can be an alternative to commonly used machines in industry. Development of electronics and power elements and their price drop has also significant meaning.

Switched Reluctance Machine works in nonlinear part of magnetization characteristics, phase currents have pulse character therefore the mathematical description of the machine is difficult to obtain in nonlinear circuit simulation models. An analytical description of flux characteristics $\psi(\theta, i)$ can be good solution for mentioned problems and they can be obtained using following

1 Adam Powrózek, Politechnika Rzeszowska, Wydział Elektrotechniki i Informatyki, ul. W. Pola 2, 35-959 Rzeszów, e-mail: apow@ @rz.edu.pl. 
methods: computational $[3,4]$ or measurement $[5,6]$. A suitable solution is to obtain flux characteristics by field calculations and then tabulate them and use in circuit model of the machine [8]. This solution gives sufficient accuracy of calculations in short time period.

The aim of this paper are simulation studies of Switched Reluctance Machine working in steady-state with various methods of control, based on nonlinear simulation model developed in Matlab/Simulink. An influence of working point change on motor properties was analyzed.

\section{Simulation model of $8 / 6 \mathrm{SRM}$}

Simulation model of SRM was presented by author in [9] with one-pulse control and following assumptions were included:

- negligibly small couplings between phases,

- magnetic circuit may operate in saturation region,

- negligible rotor core losses.

Simulation model was performed based on mathematical model presented in $[1,2]$, where after excluding couplings between phases voltage equations are written as (for $\mathrm{k}=1, \ldots, 4)$ :

$$
u_{k}=R_{k} i_{k}+\frac{d}{d t} \psi_{k}\left(\theta, i_{k}\right)
$$

and the expression of electromagnetic torque is written as:

$$
T_{e}=\sum_{k=1}^{N}\left(\frac{\partial}{\partial \theta} \int_{0}^{i_{k}} \psi_{k}\left(\theta, i_{k}^{-}\right) d i_{k}^{-}\right)
$$

Basic parameters of simulated SRM machine were shown in table 1. Flux-anglecurrent characteristics (from field calculations) and torque-angle-current characteristics (from equation 2) were determined, tabulated and used to elaborate the simulation model for steady-state analysis including above-mentioned assumptions and with basic methods of control:

- current control (soft-chopping, hard-chopping),

- voltage control (soft, hard),

- single-pulse control.

Control block can be changed according to control method. Control angles $\theta_{o n}$ and $\theta_{\text {off }}$ and angular speed of rotor $\omega$ are input parameters for all methods of control. For voltage control additional input parameters are: switching transistor 
frequency $f$ and duty cycle $D$, while for current control the additional parameter is reference current $I_{r e f}$.

Table 1. Basic parameters of 8/6 SRM

\begin{tabular}{|l|l|}
\hline Rated power & $750 \mathrm{~W}$ \\
\hline Rated speed & $3000 \mathrm{rev} / \mathrm{min}$ \\
\hline Rated voltage & $24 \mathrm{~V} \mathrm{DC}$ \\
\hline Rated torque & $2,5 \mathrm{Nm}$ \\
\hline Maximum torque & $13 \mathrm{Nm}$ \\
\hline
\end{tabular}

The asymmetric bridge converter was used to supply the motor. It was realized based on SimPowerSystems library, which contains for example models of semiconductor elements or power supplies. Controllable current sources and voltage measurement blocks were also used. Final simulation model of SRM motor for steady-state analysis was shown in the picture 1 .

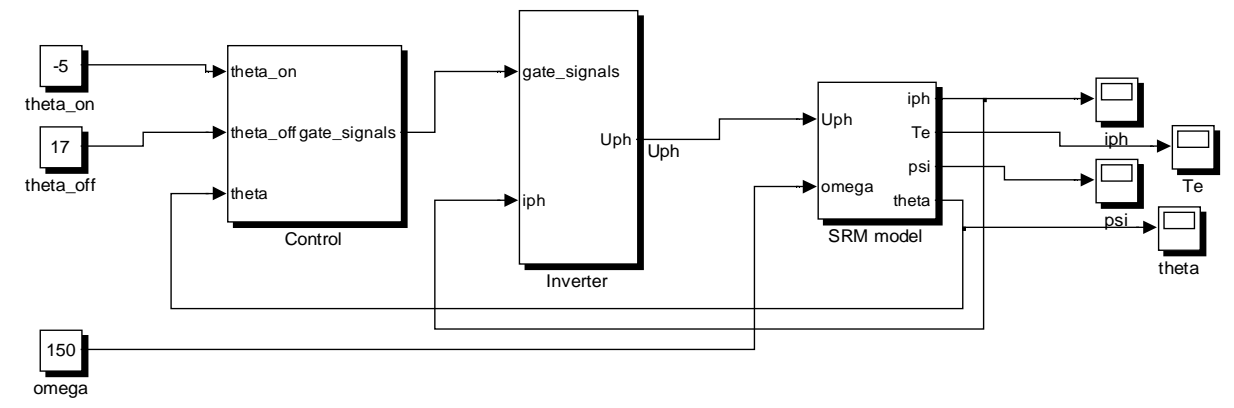

Fig 1. Simulation model of SRM for steady-state analysis

\section{Results of simulation studies}

Simulation studies were conducted for four-phase 8/6 SRM motor in steady-state with basic methods of control (current control: soft-chopping and hard-chopping, voltage control: soft and hard, and one-pulse control). Studies were concerned the change of working point influence of motor on basic parameters especially on electromagnetic torque with various basic control methods.

\subsection{Current control}

Using hysteresis current regulation it is possible to achieve soft and hard current regulation. Voltage across the winding equals in soft-chopping approximately $U_{d c}$ and 0 , while in hard-chopping it equals $U_{d c}$ and $-U_{d c}$. Soft-chopping is usually used in motoring, while hard-chopping is mainly used in generation or 
braking modes, because of difficult conditions to fast current decay in decreasing inductance area [1]. Negative voltage causes faster current decay. Graphs for motoring with current hard-chopping control for two working points of motor and different value of reference current were shown in figures 2 and 3. It was assumed that point $0^{\circ}$ occurs in position where phase inductance reaches minimum value. Characteristics of phase voltage $U_{p h}$ and phase current $i_{p h}$ as a function of rotor position were shown in figures $2 \mathrm{a}, 2 \mathrm{~b}, 3 \mathrm{a}, 3 \mathrm{~b}$.

a)

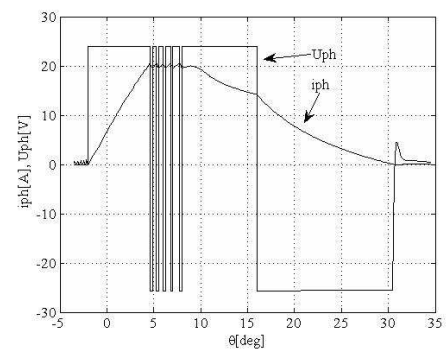

c)

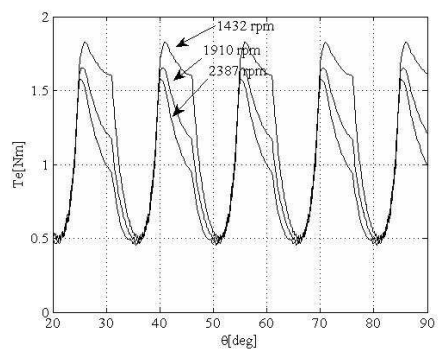

b)

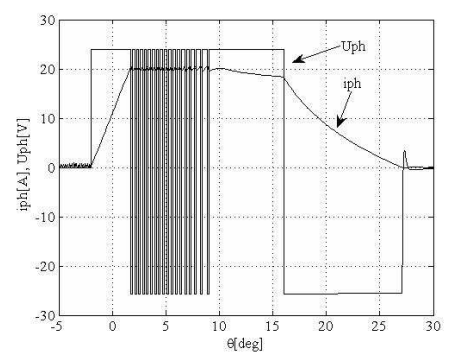

d)

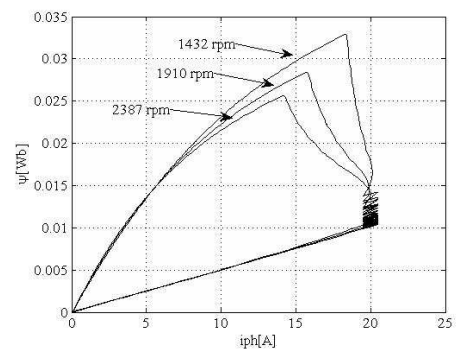

Fig. 2. Motoring with current hard-chopping control, at $\theta_{o n}=-2^{\circ}, \theta_{\text {off }}=18^{\circ}$ and $I_{r e f}=20 \mathrm{~A}$ : a) phase voltage $U_{p h}$ and phase current $i_{p h}$ at $\left.1432 \mathrm{rev} / \mathrm{min}, \mathrm{b}\right)$ phase voltage $U_{p h}$ and phase current $i_{p h}$ at $2387 \mathrm{rev} / \mathrm{min}, \mathrm{c})$ electromagnetic torque $T_{e}$ for three rotor speeds, d) flux linkage $\psi$ as a function of current $i_{p h}$ for three rotor speeds

Graphs $2 \mathrm{c}$ and $3 \mathrm{c}$ show electromagnetic torque $T_{e}$ as a function of rotor position for three various rotor speeds, whereas graphs $2 \mathrm{~d}$ and $3 \mathrm{~d}$ show comparison between flux linkage $\psi$ as a function of phase current $i_{p h}$ for three working points of motor. Graphs for motoring with current soft-chopping control for two various working points of motor and different value of reference current were shown in figures 4 and 5 . Graphs $4 a, 4 b$ and $5 a, 5 b$ show electromagnetic torque $T_{e}$ as a function of rotor position for three various rotor speeds, whereas graphs $4 \mathrm{~d}$ and $5 \mathrm{~d}$ show comparison between flux linkage $\psi$ as a function of phase current $i_{p h}$ for three working points of motor. 
a)
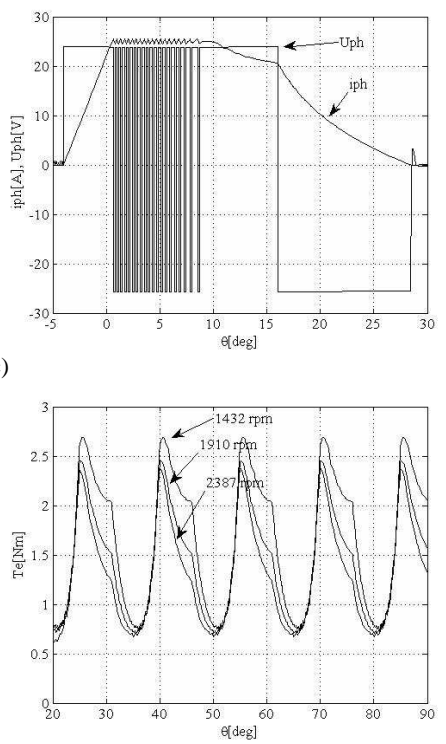

b)

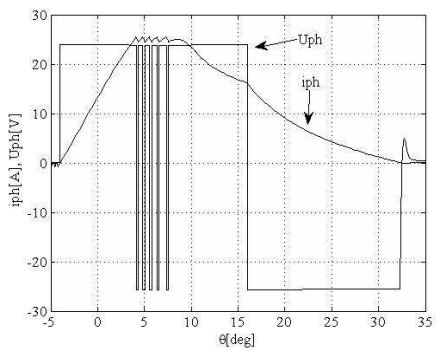

d)

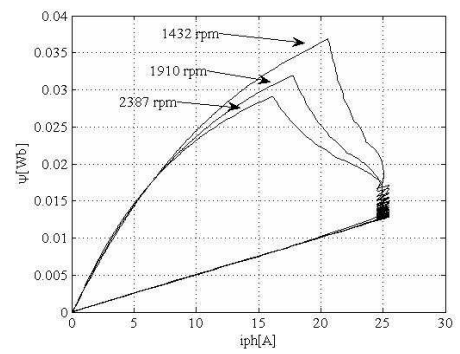

Fig.3. Motoring with current hard-chopping control, at $\theta_{o n}=-4^{\circ}, \theta_{o f f}=20^{\circ}$ and $I_{r e f}=25 \mathrm{~A}$ : a) phase voltage $U_{p h}$ and phase current $i_{p h}$ at $\left.1432 \mathrm{rev} / \mathrm{min}, \mathrm{b}\right)$ phase voltage $U_{p h}$ and phase current $i_{p h}$ at $2387 \mathrm{rev} / \mathrm{min}, \mathrm{c}$ ) electromagnetic torque $T_{e}$ for three rotor speeds, d) flux linkage $\psi$ as a function of current $i_{p h}$ for three rotor speeds
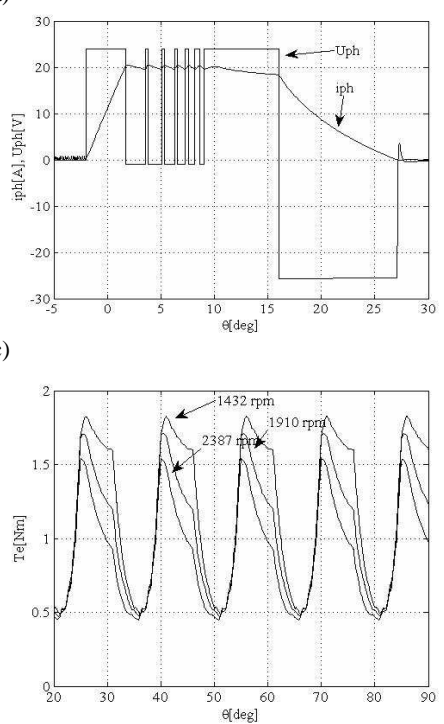

b)

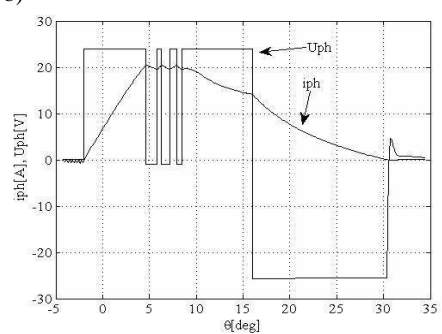

d)

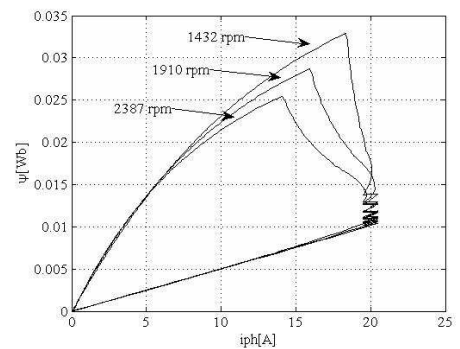

Fig.4. Motoring with current soft-chopping control, at $\theta_{o n}=-2^{\circ}, \theta_{o f f}=18^{\circ}$ and $I_{r e f}=20 \mathrm{~A}$ : a) phase voltage $U_{p h}$ and phase current $i_{p h}$ at $\left.1432 \mathrm{rev} / \mathrm{min}, \mathrm{b}\right)$ phase voltage $U_{p h}$ and phase current $i_{p h}$ at $2387 \mathrm{rev} / \mathrm{min}, \mathrm{c}$ ) electromagnetic torque $T_{e}$ for three rotor speeds, d) flux linkage $\psi$ as a function of current $i_{p h}$ for three rotor speeds 
In soft-chopping by using zero-state voltage, frequency of switching decreases compared to hard-chopping leading to limit switching losses. Current control is mainly used in operation with constant torque to base speed.

a)

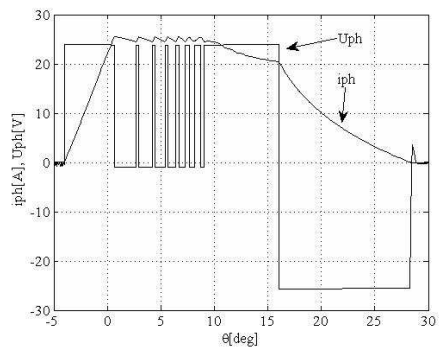

c)

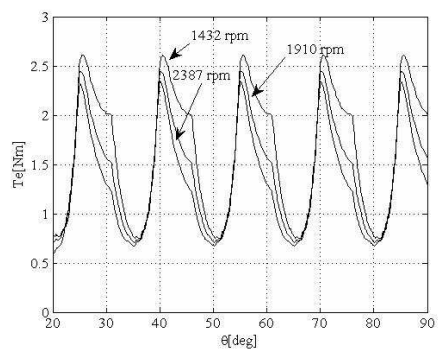

b)

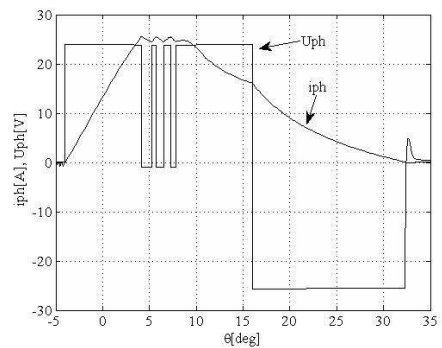

d)

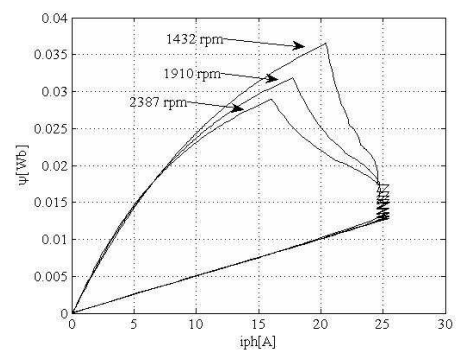

Fig.5. Motoring with current soft-chopping control, at $\theta_{\text {on }}=-4^{\circ}, \theta_{o f f}=20^{\circ}$ and $I_{r e f}=25 \mathrm{~A}$ : a) phase voltage $U_{p h}$ and phase current $i_{p h}$ at $\left.1432 \mathrm{rev} / \mathrm{min}, \mathrm{b}\right)$ phase voltage $U_{p h}$ and phase current $i_{p h}$ at $2387 \mathrm{rev} / \mathrm{min}, \mathrm{c})$ electromagnetic torque $T_{e}$ for three rotor speeds, d) flux linkage $\psi$ as a function of current $i_{p h}$ for three rotor speeds

\subsection{Voltage control}

In voltage control pulse width modulation (PWM) is used where at least one branch transistor must be controlled with frequency $f$ and duty cycle $D$ [7]. Voltage control divides into hard control where both transistors in branch are controlled and soft control where only one transistor is controlled and second is always turned on.

Graphs for motoring with hard voltage control for two various working points and different rotor speeds were shown in figures 6 and 7. Characteristics of phase voltage $U_{p h}$ and phase current $i_{p h}$ for $1432 \mathrm{rev} / \mathrm{min}$ and $2387 \mathrm{rev} / \mathrm{min}$ were shown in figures $6 \mathrm{a}, 6 \mathrm{~b}$ and $7 \mathrm{a}, 7 \mathrm{~b}$. If speed increases, back emf also increases and it causes phase current drop, because $\mathrm{di} / \mathrm{dt}$ is negative. With increasing the speed, phase current decreases faster what leads to electromagnetic torque decrease (fig. $6 \mathrm{c}$ and $7 \mathrm{c}$ ). 
a)
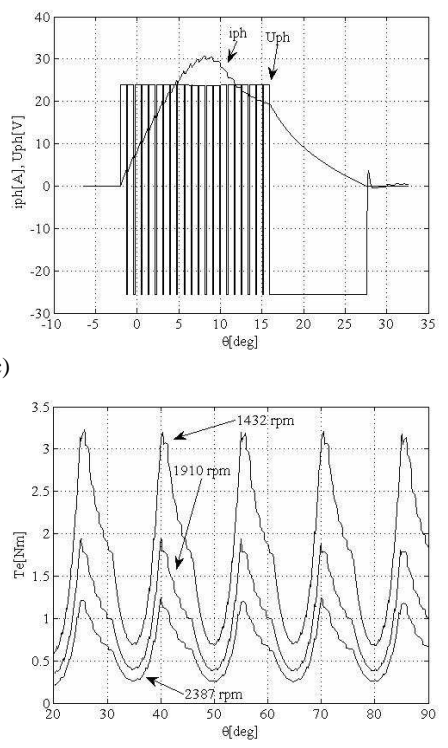

b)

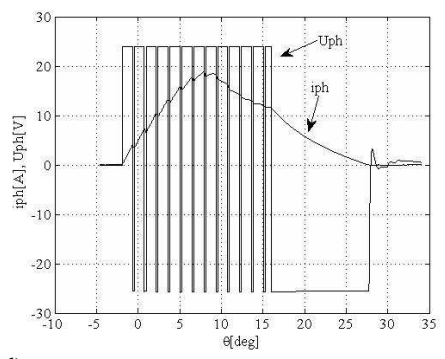

d)

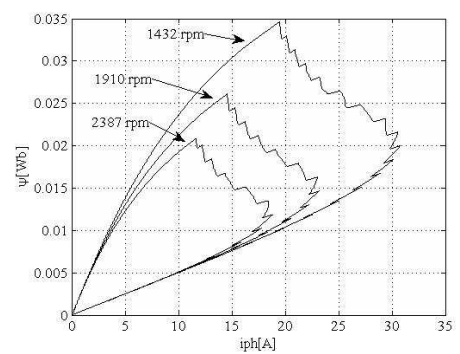

Fig.6. Motoring with hard voltage control, at $\theta_{o n}=-2^{\circ}, \theta_{o f f}=18^{\circ}$ and $D=85 \%$ : a) phase voltage $U_{p h}$ and phase current $i_{p h}$ at $1432 \mathrm{rev} / \mathrm{min}, \mathrm{b}$ ) phase voltage $U_{p h}$ and phase current $i_{p h}$ at $2387 \mathrm{rev} / \mathrm{min}$, c) electromagnetic torque $T_{e}$ for three rotor speeds, d) flux linkage $\psi$ as a function of current $i_{p h}$ for three rotor speeds
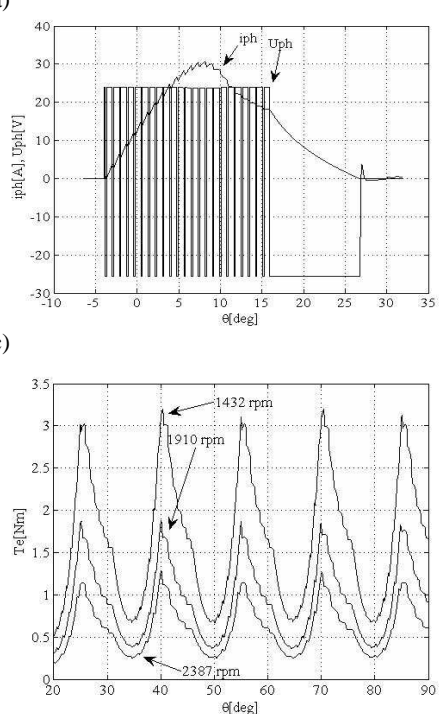

b)

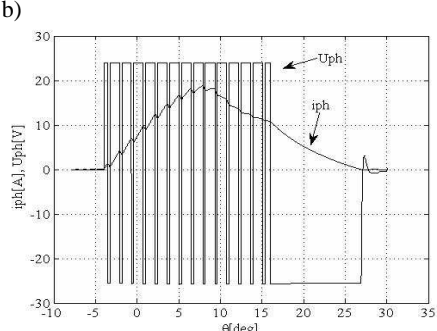

d)

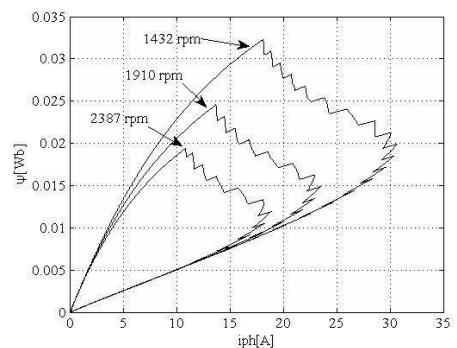

Fig.7. Motoring with hard voltage control, at $\theta_{o n}=-4^{\circ}, \theta_{o f f}=20^{\circ}$ and $D=80 \%$ : a) phase voltage $U_{p h}$ and phase current $i_{p h}$ at $\left.1432 \mathrm{rev} / \mathrm{min}, \mathrm{b}\right)$ phase voltage $U_{p h}$ and phase current $i_{p h}$ at $2387 \mathrm{rev} / \mathrm{min}$, c) electromagnetic torque $T_{e}$ for three rotor speeds, d) flux linkage $\psi$ as a function of current $i_{p h}$ for three rotor speeds 
Comparison between flux linkage $\psi$ as a function of phase current $i_{p h}$ for three working points of motor were shown in figures $6 \mathrm{~d}$ and $7 \mathrm{~d}$. The area designated by particular curves is proportional to average electromagnetic torque produced by one motor phase [1]. In figures 6 and 7 it is seen that despite the expansion of conduction band, duty cycle has significant influence on motor performances.

Graphs for motoring with soft voltage control was shown in figures 8 and 9. On these graphs it can be seen that with increasing the speed similarly like at hard voltage control, phase current decreases but at soft voltage control it can be seen significant increase of motor performances in comparison with hard voltage control. This results from average voltage value on phase of motor.

a)

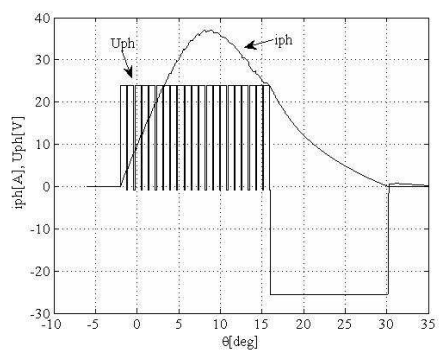

c)

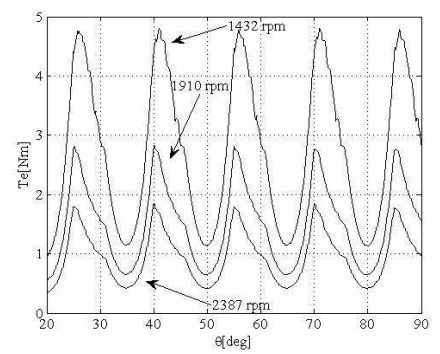

b)

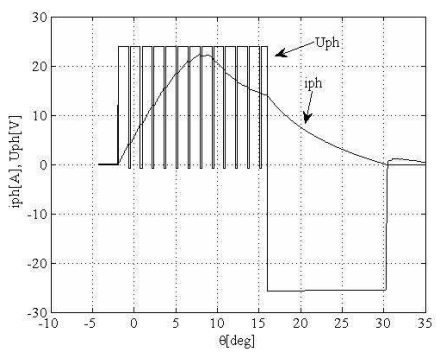

d)

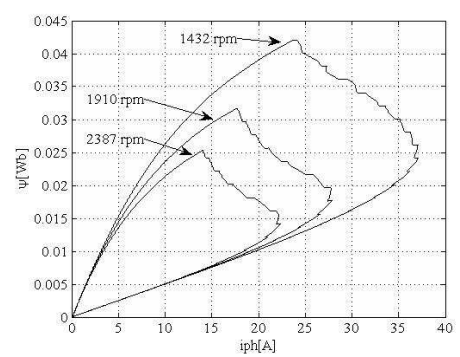

Fig.8. Motoring with soft voltage control, at $\theta_{\text {on }}=-2^{\circ}, \theta_{o f f}=18^{\circ}$ and $D=85 \%$ : a) phase voltage $U_{p h}$ and phase current $i_{p h}$ at $\left.1432 \mathrm{rev} / \mathrm{min}, \mathrm{b}\right)$ phase voltage $U_{p h}$ and phase current $i_{p h}$ at $2387 \mathrm{rev} / \mathrm{min}, \mathrm{c}$ ) electromagnetic torque $T_{e}$ for three rotor speeds, d) flux linkage $\psi$ as a function of current $i_{p h}$ for three rotor speeds

\subsection{Single-pulse control}

Single-pulse control is a particular case of voltage control where duty cycle D of PWM signal equals 1. It is used mainly in high-speed operation where due to low frequency of carrier wave of PWM signal, voltage regulation is ineffective and speed regulation is only by changing of control angles [7]. Graphs for motoring with one-pulse control for two various working points of motor were shown in figures 10 and 11. 
a)

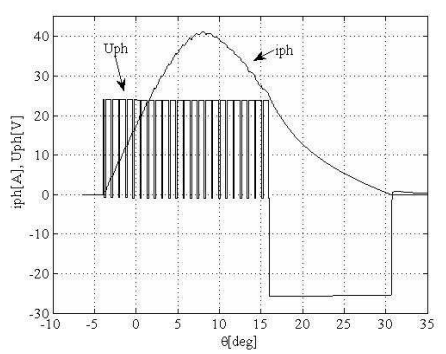

c)

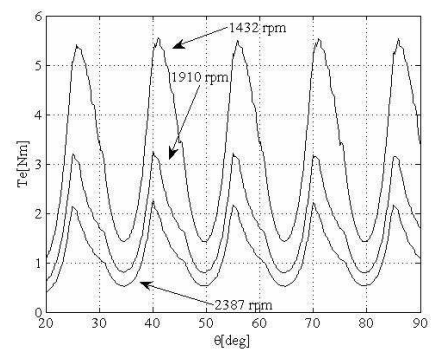

b)

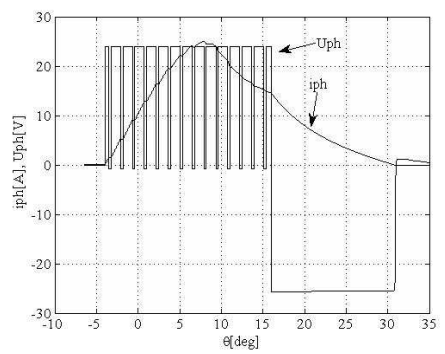

d)

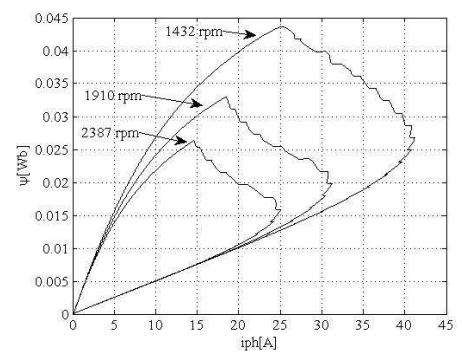

Fig.9. Motoring with soft voltage control, at $\theta_{o n}=-4^{\circ}, \theta_{o f f}=20^{\circ}$ and $D=80 \%$ : a) phase voltage $U_{p h}$ and phase current $i_{p h}$ at $1432 \mathrm{rev} / \mathrm{min}, \mathrm{b}$ ) phase voltage $U_{p h}$ and phase current $i_{p h}$ at $2387 \mathrm{rev} / \mathrm{min}, \mathrm{c}$ ) electromagnetic torque $T_{e}$ for three rotor speeds, d) flux linkage $\psi$ as a function of current $i_{p h}$ for three rotor speeds
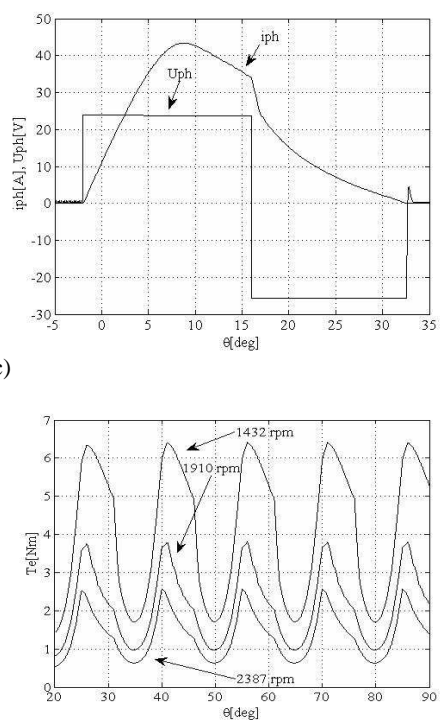

b)

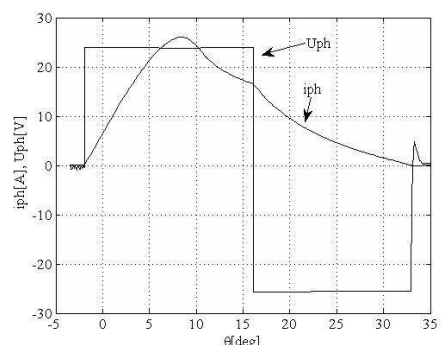

d)

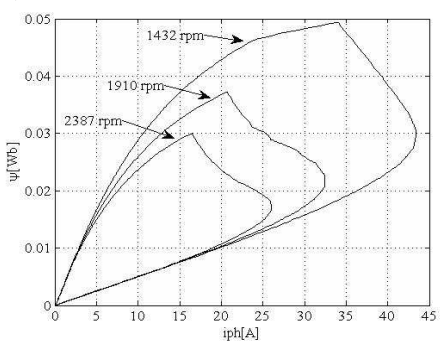

Fig.10. Motoring with single-pulse control, at $\theta_{o n}=-2^{\circ}, \theta_{\text {off }}=18^{\circ}$ : a) phase voltage $U_{p h}$ and phase current $i_{p h}$ at $1432 \mathrm{rev} / \mathrm{min}, \mathrm{b}$ ) phase voltage $U_{p h}$ and phase current $i_{p h}$ at $2387 \mathrm{rev} / \mathrm{min}, \mathrm{c}$ ) electromagnetic torque $T_{e}$ for three rotor speeds, d) flux linkage $\psi$ as a function of current $i_{p h}$ for three rotor speeds 
Graphs of phase voltage $U_{p h}$ and phase current $i_{p h}$ as the function of rotor position were shown in figures $10 \mathrm{a}, 10 \mathrm{~b}, 11 \mathrm{a}, 11 \mathrm{~b}$ and graphs of electromagnetic torque $T_{e}$ for three various rotor speeds were shown in figures $10 \mathrm{c}$ and $11 \mathrm{c}$. Figures $10 \mathrm{~d}$ and $11 \mathrm{~d}$ show dependencies of flux linkage $\psi$ as a function of phase current $i_{p h}$ for three rotor speeds. The area designated by particular curves is proportional to average electromagnetic torque produced by one motor phase. It is seen that with increasing the speed area decreases what leads to decreasing of electromagnetic torque (fig. 10c and 11c).

a)

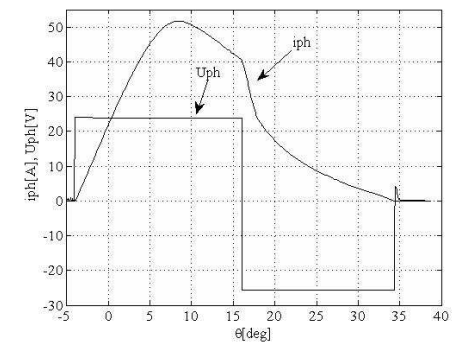

c)

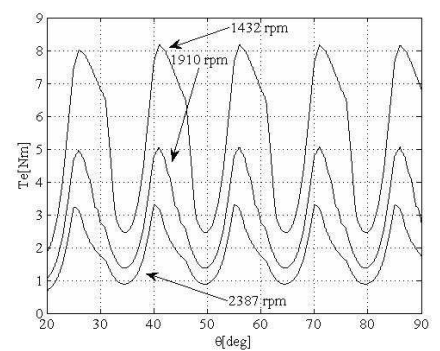

b)

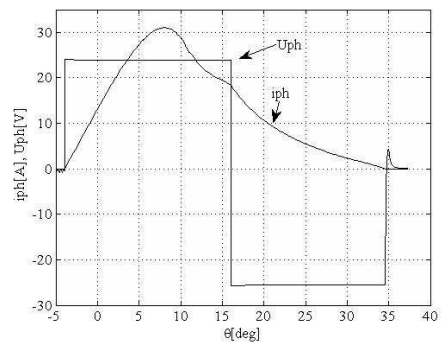

d)

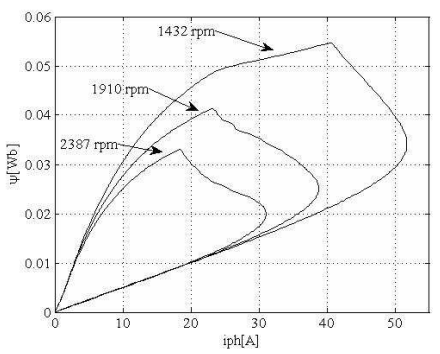

Fig.11. Motoring with single-pulse control, at $\theta_{o n}=-4^{\circ}, \theta_{o f f}=20^{\circ}$ : a) phase voltage $U_{p h}$ and phase current $i_{p h}$ at $\left.1432 \mathrm{rev} / \mathrm{min}, \mathrm{b}\right)$ phase voltage $U_{p h}$ and phase current $i_{p h}$ at $2387 \mathrm{rev} / \mathrm{min}$, c) electromagnetic torque $T_{e}$ for three rotor speeds, d) flux linkage $\psi$ as a function of current $i_{p h}$ for three rotor speeds

\section{Conclusions}

In paper was presented control methods analysis of SRM motor. The analysis of working point change influence on motor properties was achieved for various methods of control. Using hysteresis regulator in current control, phase current is held at a certain level what gives constant average electromagnetic torque. In practice it can be met many types of current control, but in this paper author was only focused on basic types of current control. Current control is possible to base speed, because with increasing the speed back emf also increases and this makes that current control is impossible to obtain, because of limited value of supply voltage. Voltage control with its particular case called singlepulse control has wider use because it can be used above base speed, but for 
high-speed operation single-pulse control is used, where speed regulation is obtained by changing of control angles.

\section{References}

[1] Miller T. J. E.: Electronic Control of Switched Reluctance Machines, Newnes, 2001.

[2] Krishnan R.: Switched Reluctance Motor Drives: Modeling, Simulation, Analysis, Design, and Applications, CRC Press, 2001.

[3] Lobato P., Rafael S., Santos P., Pires A. J.: Magnetic Characteristics Modelling for Regular Switched Reluctance Machines: Analytical and FEM Approaches, Power Engineering, Energy and Electrical Drives, 2009, 60-65.

[4] Ramasamy G., Rajandran R.V., Saho N.,C.: Modeling of Switched Reluctance Motor Drive using Matlab/Simulink for Performance Analysis of Current Controllers, IEEE PEDS, 2005, 892-897.

[5] Carstensen C.E., Fuengwarodsakul N., De Doncker R.W.:Flux Linkage Determination for Correct Modeling of Switched Reluctance Machine - Dynamic Measurement versus Static Computation, Electric Machines \& Drives Conference, 2007. IEMDC '07. IEEE International, Volume:2, 1317-1323.

[6] Ramanarayanan, V., Venkatesha, L., Debiprasad Panda: Flux-linkage characteristics of switched reluctance motor, Power Electronics, Drives and Energy Systems for Industrial Growth, 1996, 281-285.

[7] Bogusz P.: Silnik reluktancyjny przełączalny sterowany z procesora sygnałowego, Rozprawa doktorska, Warszawa 2003.

[8] Bogusz P., Korkosz M., Powrózek A., Prokop J.: Modelowanie pracy silnikowoprądnicowej napędu z maszyną reluktancyjną przełączalną, Przegląd Elektrotechniczny (Electrical Review), NR 12a/2012, str. 56-61.

[9] Powrózek A.: Model symulacyjny maszyny reluktancyjnej przełączalnej, Zeszyty Naukowe Politechniki Rzeszowskiej "Elektrotechnika" z. 32, 2012, 45-56.

\section{ANALIZA METOD STEROWANIA MASZYNĄ RELUKTANCYJNĄ PRZEŁĄCZALNA}

\section{Streszczenie}

W pracy przedstawiono wyniki badań symulacyjnych czteropasmowej maszyny SRM 8/6 pracującej w stanie ustalonym. Model symulacyjny opracowano w systemie Matlab/Simulink w oparciu o model matematyczny maszyny. Model symulacyjny zrealizowano w oparciu o bibliotekę SimPowerSystems, która zawiera przykładowo elementy półprzewodnikowe, źródła napięcia, sterowane źródła prądowe oraz bloki do pomiaru napięcia. Opis matematyczny maszyny SRM jest trudny do realizacji w nieliniowych obwodowych modelach symulacyjnych. Charakterystyki strumieniowe $\psi(\theta, i)$ wyznaczono metodami polowymi i wykorzystano do budowy modelu obwodowego maszyny. Przeprowadzono analizę wpływu zmiany punktu pracy na właściwości maszyny przy różnych metodach sterowania (sterowanie prądowe, napięciowe i jednopulsowe). W przypadku sterowania prądowego wykorzystano tylko regulator histerezowy, który utrzymywał wartość prądu pasmowego na określonym poziomie. Sterowanie prądowe możliwe jest do tzw. prędkości bazowej, podczas gdy sterowanie napięciowe wraz ze szczególnym przypadkiem sterowania 
jednopulsowego może być stosowane powyżej prędkości bazowej, ale dla pracy wysokoobrotowej stosowane jest sterowanie jednopulsowe.

Słowa kluczowe: model symulacyjny, sterowanie prądowe, sterowanie napięciowe, sterowanie jednopulsowe

DOI: $10.7862 /$ re.2013.14

Tekst złożono $w$ redakcji: lipiec 2013

Przyjęto do druku: grudzień 2013 